\title{
PERMASALAHAN PENEGAKAN HUKUM TERHADAP SITUS INTERNET DENGAN KONTEN NEGATIF MELALUI PEMBLOKIRAN SITUS
}

\author{
oleh \\ Joko Suroso
}

\begin{abstract}
Abstrak
Tulisan ini bertujuan untuk membedah mengenai aturan Penegakan Hukum Terhadap Situs Internet Dengan Konten Negatif Melalui Pemblokiran Situs dan berusaha untuk memberikan pandangan dan masukan terhadap aturan tersebut, sehingga diharapkan pemerintah dapat menjalankan kewajibannya tanpa melanggar prinsip-prinsip demokrasi dan hak dasar warga negara. Metode penelitian yang digunakan adalah metode penelitian kepustakaan dengan pendekatan yuridis normatif. Bahan hukum sekunder dan tersier dipelajari, dianalisis dan kemudian dituliskan secara deskriptif analitis. Kewenangan pemerintah untuk melakukan pemblokiran situs internet bermuatan negatif telah diperkuat melalui UU No. 11 Tahun 2008 Tentang Perubahan UU No. 11 Tahun 2008 Tentang Informasi dan Transaksi Elektronik. Namun, pengertian mengenai konten negatif dan ilegal yang ditetapkan oleh pemerintah dipandang terlalu luas dan multitafsir. Selain itu, perlu dikembangkan model pemblokiran situs internet yang transparan dan akuntabel.
\end{abstract}

Kata kunci: penegakan hukum, informasi dan transaksi elektronik, pemblokiran, situs internet bermuatan negatif

\section{PENDAHULUAN}

Kementerian Komunikasi dan Informatika telah melakukan banyak pemblokiran situs. Situs-situs yang diblokir diindikasikan memiliki konten negatif seperti pornografi, perjudian, penipuan, SARA dan kegiatan ilegal lainnya. Bila dirinci, jumlah situs yang diblokir terus bertambah seiring tahun. Pada 2014 jumlah pemblokiran baru sebanyak 3.694 situs. Pada 2015 bertambah menjadi 5.543 situs. Ada sedikit penurunan pada 2016 yaitu sebanyak 5.159 situs, sebelum akhirnya naik lagi pada 2017. ${ }^{1}$ Terkait situs dengan indikasi konten mengandung unsur radikalisme, terdapat pula peningkatan pemblokiran. Pada 2014 tidak ada situs dengan indikasi konten mengandung unsur radikalisme yang diblokir, namun pada 2015 ada 37 situs dengan indikasi konten mengandung unsur radikalisme yang diblokir. Jumlahnya naik menjadi 48 situs diblokir pada 2016 dan melonjak menjadi 111 situs diblokir. Salah satu hal yang membuat tingginya angka ini karena adanya kerja sama Kominfo dengan Polri untuk memblokir konten-konten di media daring yang dinilai mengandung muatan radikalisme. ${ }^{2}$

Pemblokiran yang dilakukan oleh Kominfo mendapatkan reaksi dari masyarakat. Terdapat pihak yang menolak dilakukannya pemblokiran yang dipandang dilakukan sepihak oleh Kominfo. Seperti yang disampaikan oleh pengelola suarapapua.com yang merasa tidak mendapatkan pemberitahuan apapun dari Kemenkominfo, baik telepon, email maupun surat resmi terkait pemblokiran situsnya. Sehingga mereka tidak memahami alasan diblokirnya situs

${ }^{1}$ https://tirto.id/aksi-blokir-situs-oleh-pemerintah-bermanfaatkah-cGf7?gclid= Cj0KCQjw6J 7YBRC4ARIs AJMXXsdFto18juU jWx8Yf_XyLuijnN7PpU9DnFLPorE6pGQQeK_wkbJxwgaAnXSEALw_wcB, diakses pada 25 Mei 2018, pukul 13.05 wib ${ }^{2}$ Ibid., 
mereka. Protes serupa juga disampaikan oleh pengelola situs smstauhid.com, yaitu AA Gym, yang mempertanyakan mengenai salah satu situsnya yang diblokir. Walaupun sekarang, situs smstauhid.com sudah bisa diakses kembali. ${ }^{3}$

Penutupan akses terhadap sejumlah situs tersebut telah memancing pro dan kontra dikalangan masyarakat. Banyak yang mempertanyakan alasan penutupan akses tersebut. Meskipun pemerintah melalui pada UU No. 19 Tahun 2016 tentang Perubahan Atas UndangUndang Nomor 11 Tahun 20018 Tentang ITE, serta Peraturan Menteri Komunikasi dan Informatika Nomor 19 Tahun 2014 tentang Penanganan Situs Internet Bermuatan Negatif telah memberi pengaturan mengenai hal tersebut. Dalam kedua aturan tersebut memberikan wewenang mutlak pemerintah dalam melakukan pemblokiran Situs Internet Bermuatan Negatif.

Tulisan ini bertujuan untuk membedah mengenai aturan penegakan hukum terhadap situs internet yang dianggap berkonten negatif melalui pemblokiran dan berusaha untuk memberikan pandangan dan masukan terhadap aturan tersebut, sehingga diharapkan pemerintah dapat menjalankan kewajibannya tanpa melanggar prinsip-prinsip demokrasi dan hak dasar warga negara.

\section{METODE PENELITIAN}

Metode penelitian yang digunakan adalah metode penelitian kepustakaan dengan pendekatan yuridis normatif. ${ }^{4}$ Bahan hukum sekunder dipelajari, dianalisis dan kemudian dituliskan secara deskriptif analitis. Penulisan ini akan dilakukan melalui penelitian kepustakaan untuk mencari konsepsi-konsepsi, teori-teori, pendapat hukum ataupun penemuan hukum yang berhubungan erat dengan pokok permasalahan. ${ }^{5}$

\section{PEMBAHASAN}

Sejak berlakunya Undang-undang Nomor 11 Tahun 2008 tentang Informasi dan Transaksi Elektronik (UU ITE), Pemerintah telah memiliki kewajiban untuk melindungi kepentingan umum dari segala jenis gangguan akibat penyalahgunaan informasi elektronik dan transaksi elektronik yang mengganggu ketertiban umum, sesuai dengan ketentuan peraturan perundang-undangan.

Hal tersebut tertulis pada bab mengenai peran pemerintah dan peran masyarakat, Pasal 40 ayat (1) dan ayat (2) dalam UU ITE sebelum perubahan, yang berbunyi:

"(1) Pemerintah memfasilitasi pemanfaatan Teknologi Informasi dan Transaksi Elektronik sesuai dengan ketentuan peraturan perundang-undangan.

(2) Pemerintah melindungi kepentingan umum dari segala jenis gangguan sebagai akibat penyalahgunaan informasi elektronik dan transaksi elektronik yang mengganggu ketertiban umum, sesuai dengan ketentuan peraturan perundang-undangan."

\footnotetext{
3 https://tirto.id/ketika-pemerintah-makin-digdaya-memblokir-situsnbsp-nbsp-b5tq, diakses pada 25 Mei 2018 , pukul 13.30 wib

${ }^{4}$ Soerjono Soekanto. Pengantar Penelitian Hukum, cet.3. Jakarta: UI-Press, 1986.., hlm. 11.

${ }^{5}$ Ibid., hlm. 22.
} 
Pada tahun 2014, terbit Peraturan Menteri Komunikasi dan Informatika (Permen Kominfo) Nomor 19 Tahun 2014 tentang Penanganan Situs Internet Bermuatan Negatif. Peraturan Menteri ini kemudian diikuti dengan serangkaian penutupan akses terhadap sejumlah situs yang dinilai bermuatan negatif.

Kemudian, pada perubahan UU ITE yang dilaksanakan pada tahun 2016, kewenangan pemerintah dalam menjalankan kewajibannya dalam melindungi kepentingan umum dari segala jenis gangguan sebagai akibat penyalahgunaan informasi elektronik dan transaksi elektronik yang mengganggu ketertiban umum, ditambahkan ke dalam UU ITE tersebut, yaitu dengan penambahan ayat (2a) dan ayat (2b) pada Pasal 40 UU ITE, sehingga menjadi sebagai berikut:

"(1) Pemerintah memfasilitasi pemanfaatan teknologi informasi dan transaksi elektronik sesuai dengan ketentuan peraturan perundang-undangan.

(2) Pemerintah melindungi kepentingan umum dari segala jenis gangguan sebagai akibat penyalahgunaan informasi elektronik dan transaksi elektronik yang mengganggu ketertiban umum, sesuai dengan ketentuan peraturan perundang-undangan.

(2a) Pemerintah wajib melakukan pencegahan penyebarluasan dan pengggunaan informasi elektronik dan/atau dokumen elektronik yang memiliki muatan yang dilarang sesuai dengan ketentuan peraturan perundang-undangan.

(2b) dalam melakukan pencegahan sebagaimana dimaksud pada ayat (2a), pemerintah berwenang melakukan pemutusan akses dan/atau memerintahkan kepada penyelenggara system elektronik untuk melakukan pemutusan akses terhadap informasi elektronik dan/atau dokumen elektronik yang memiliki muatan yang melanggar hukum."

Ketentuan baru yang ditambahkan pada Pasal 40 UU ITE tersebut memiliki dua mata pisau. Disatu sisi, berusaha untuk melindungi kepentingan umum dari segala jenis gangguan sebagai akibat dari penyalahgunaan informasi elektronik dan transaksi elektronik yang mengganggu ketertiban umum, namun disisi yang lain dapat melukai semangat demokrasi dan hak dasar warga negara, dikarenakan begitu besarnya kewenangan yang dimiliki oleh pemerintah dalam menentukan dan memutuskan pemutusan akses atau pemblokiran suatu situs yang dianggap telah melanggar hukum. Selain itu, transparansi proses dan alasan pemblokiran serta pertanggungjawaban pengelola situs apabila terbukti mengelola situs yang mengandung unsur negatif pun terus menjadi pertanyaan.

Penegakan hukum terhadap Situs Internet Dengan Konten Negatif dengan pertanyaan yang timbul ditas menjadi hal yang kurang jelas. Secara konsepsional, inti dari penegakan hukum menurut Soerjono Soekanto terletak pada kegiatan menyerasikan hubungan nilai-nilai yang terjabarkan di dalam kaidah-kaidah yang mantap dan mengejawantahkan serta sikap tindak sebagai rangkaian penjabaran nilai tahap akhir, untuk menciptakan, memelihara dan mempertahankan kedamaian pergaulan hidup. ${ }^{6}$ Penegakan hukum bukanlah semata-mata berarti pelaksanaan perundang-undangan namun juga sebagai pelaksanaan keputusankeputusan hakim. ${ }^{7}$

\footnotetext{
${ }^{6}$ Soerjono Soekanto, “Penegakan Hukum dan Kesadaran Hukum”, Naskah Lengkap pada paper pada seminar Hukum Nasional ke IV, Jakarta, 1979.

7 Soerjono Soekanto, Faktor-faktor yang Mempengaruhi Penegakan Hukum, Jakarta: RajaGrafindo Persada, 2004, hal. 7
} 
Mekanisme pemblokiran, diatur pada Permen Kominfo No. 19 Tahun 2014 tentang Penanganan Situs Internet Bermuatan Negatif. Permen ini menjelaskan bahwa pemblokiran adalah upaya uang dilakukan agar situs internet bermuatan negatif tidak dapat diakses. Permen Kominfo ini memiliki tujuan untuk memberikan dasar bagi pemerintah dan masyarakat dalam memahami situs internet bermuatan negatif dan peran bersama pemerintah dan masyarakat dalam penanganannya, serta melindungi kepentingan umum dari konten internet yang berpotensi memberikan dampak negatif dan/atau merugikan.

Perdebatan mengenai potensi memberikan dampak negatif dan/atau merugikan bagi kepentingan umum selalu muncul. Kepentingan umum yang dimaksud bisa sangat multitafsir dan ditafsirkan berdasarkan kepentingan masing-masing kelompok, golongan dan bahkan individu. Sehingga, penting untuk memberikan batasan yang jelas mengenai maksud dari kepentingan umum tersebut dan potensi dampak negatif dan/atau merugikan yang dimaksud.

Menurut Pasal 4 Permen Kominfo tersebut, situs internet bermuatan negatif yang ditangani adalah pornografi dan kegiatan illegal lainnya berdasarkan ketentuan peraturan perundang-undangan. Kegiatan illegal yang dimaksud adalah kegiatan illegal yang pelaporannya berasal dari kementrian atau lembaga pemerintah yang berwenang sesuai ketentuan peraturan perundang-undangan.

Apabila diperhatikan, pengertian mengenai situs internet bermuatan negatif ini mengandung beberapa persoalan. Untuk situs yang dengan jelas berkonten pornografi, sudah dapat dipahami dengan seketika. Walaupun, pernah ada preseden pemblokiran yang dipandang tidak tepat juga, yaitu pemblokiran beberapa situs kesehatan yang bersifat edukatif. Situs kesehatan edukatif memperlihatkan payudara perempuan dalam memberikan Air Susu Ibu. Situs tersebut diblokir tanpa ada alasan yang jelas, namun kuat diduga karena dipandang merupakan bagian dari pornografi.

Pengertian mengenai kegiatan ilegal lainnya dipandang terlalu luas. Kegiatan ilegal mestilah dapat dibuktikan bahwa hal tersebut adalah melanggar hukum, atau terdapat rumusan ketentuannya dalam peraturan perundang-undangan. Terkait dengan pengertian kegiatan ilegal lainnya, terdapat beberapa perbuatan melanggar hukum menurut peraturan perundangundangan diantaranya adalah pornografi, pornografi anak, perjudian, pemerasan, penipuan, kekerasan, kekerasan anak, fitnah, pencemaran nama baik, pelanggaran kekayaan intelektual, provokasi SARA, berita bohong, terorisme/radikalisme. Akan sangat baik sekali apabila konten negatif dan ilegal yang dimaksud dalam Permen Kominfo tersebut disempitkan pemaknaannya kedalam perbuatan melanggar hukum seperti yang disebutkan diatas.

Pada tahun 2015 pernah ada Forum Penanganan Situs Internet Bermuatan Negatif (FPSIBN) yang bertugas mengawasi dan memonitor berbagai situs. Tim inilah yang memberi masukan apakah sebuah situs dimasukkan kedalam daftar pemblokiran atau tidak. Masa kerja FPBSIBN berakhir pada Desember $2015 .^{8}$

Asep Saefullah, anggota FPSIBN, menyatakan selama Ia bergabung dengan FPSIBN, permintaan pemblokiran dari kementrian dan lembaga negara lainnya memang lebih banyak dibandingkan permintaan masyarakat. Namun, permintaan pemblokiran dari instansi kebanyakan tidak disertai alasan yang rasional, sehingga tim panel pemblokiran harus mencari lagi persoalannya. Hal ini yang menyebabkan banyaknya penolakan pemblokiran dari tim panel. 9

\footnotetext{
${ }^{8}$ https://tirto.id/mencari-mekanisme-pemblokiran-yang-tepat-b5tK, diakses pada 26 Mei 2018, pukul 16.00 wib
} ${ }_{9}$ Ibid. 
Berdasarkan pemaparan diatas, dapat diketahui terdapat permasalahan dalam sekedar mendasarkan alasan pemblokiran atas pelaporan dari kementrian atau lembaga pemerintah semata. Proses pemblokiran yang melalui sebuah forum seperti FPSIBN mungkin dapat dikembangkan, sehingga terdapat transparansi dan akuntabilitas dalam prosesnya. Setiap kali ada pemblokiran, pemerintah dapat menjelaskan alasan disertai bukti-bukti sehingga dapat dipertanggungjawabkan. Hal ini akan membantu dalam memberikan pendidikan kepada masyarakat mengenai situs internet yang memiliki konten negatif dan dampak negatif atau merugikan yang diakibatkannya. Selain itu, juga akan membantu dalam menjaga proses demokrasi dan penghormatan atas hak warga negara.

Bab VI Permen Kominfo No. 19 Tahun 2014 tentang Penanganan Situs Internet Bermuatan Negatif mengatur mengenai tata cara pemblokiran dan normalisasi pemblokiran, yang terdiri atas penerimaan laporan, tindak lanjut laporan dan tata cara normalisasi.

Pasal 10 Permen Kominfo mengatur mengenai tata cara pelaporan, yaitu:

a. Penerimaan laporan berupa pelaporan atas:

1. Situs internet bermuatan negatif; atau

2. Permintaan normalisasi pemblokiran situs.

b. Masyarakat menyampaikan laporan kepada Direktur Jenderal melalui fasilitas penerimaan pelaporan berupa e-mail aduan dan/atau pelaporan berbasis situs yang disediakan;

C. Pelaporan dari masyarakat dapat dikategorikan sebagai pelaporan mendesak apabila menyangkut:

1. Privasi;

2. Pornografi anak;

3. Kekerasan;

4. Suku, agama, ras dan antargolongan (SARA); dan/atau

5. Muatan lainnya yang berdampak negatif yang menjadi keresahan masyarakat secara luas.

Pasal 11 Permen Kominfo menjelaskan mengenai pelaporan yang dilakukan oleh kementrian atau lembaga, yaitu:

(1) Permintaan pemblokiran sebagaimana dimaksud dalam Pasal 5 ayat (2) harus telah melalui penilaian di kementrian atau lembaga terkait dengan memuat alamat situs, jenis muatan negatif, jenis pelanggaran dan keterangan;

(2) Permintaan pemblokiran sebagaimana dimaksud pada ayat (1) disampaikan oleh Pejabat berwenang kepada Direktur Jenderal, dengan dilampiri daftar alamat situs dan hasil penilaian;

(3) Terhadap permintaan pemblokiran sebagaimana dimaksud pada ayat (2), Direktur Jenderal melakukan pemantauan terhadap situs yang dimintakan pemblokirannya.

Kemudian, mengenai tindak lanjut laporan, diatur pada Pasal 12, 13, 14 dan Pasal 15, yaitu: Pasal 12 Kegiatan pengelolaan laporan meliputi:

a. Penyimpanan laporan asli ke dalam berkas dan data base elektronik,

b. Peninjauan dan pengambilan sampel ke situs internet yang dituju; dan

c. Penyimpanan sampel gambar situs internet ke dalam berkas dan database elektronik. 
Pasal 13 Tata cara tindak lanjut laporan dari masyarakat, meliputi:

a. Melakukan kegiatan pengelolaan laporan dalam waktu 1 X 24 (satu kali dua puluh empat) jam.

b. Apabila situs internet dimaksud merupakan situs bermuatan negatif:

1. Direktur Jenderal menempatkan alamat situs tersebut ke dalam TRUST-Positif apabila situs berupa domain;

2. Direktur Jenderal meminta kepada penyedia atau pemilik situs untuk melakukan pemblokiran atau menghapus muatan negatif apabila situs berupa selain nama domain;

3. Apabila merupakan kondisi mendesak, Direktur Jenderal menempatkan alamat situs tersebut dalam TRUST-Positif dalam periode 1 X 12 (satu kali dua belas) jam sejak laporan diterima dan dilakukan komunikasi kepada Penyelenggara Jasa Akses Internet.

Pasal 14 Tata cara tindak lanjut laporan dari Kementrian/Lembaga meliputi:

a. Direktur Jenderal memberikan peringatan melalui e-mail kepada penyedia situs untuk menyampaikan adanya muatan negatif.

b. Dalam hal penyedia situs tidak mengindahkan peringatan sebagaimana angka 1 dalam waktu 2 X 24 (dua kali dua puluh empat) jam, maka dilakukan tindak lanjut pengelolaan laporan.

C. Dalam hal tidak ada alamat komunikasi yang dapat dihubungi maka langsung dilakukan tindak lanjut pengelolaan laporan.

d. Direktur Jenderal menyelesaikan pengelolaan laporan dalam waktu paling lambat 5 (lima) hari kerja sejak pelaporan diterima.

e. Apabila situs internet dimaksud merupakan situs bermuatan negatif:

1. Direktur Jenderal menempatkan alamat situs tersebut ke dalam TRUST-Positif apabila situs berupa domain;

2. Direktur Jenderal meminta kepada penyedia atau pemilik situs untuk melakukan pemblokiran atau menghapus muatan negatif apabila situs berupa selain nama domain;

3. Apabila merupakan kondisi mendesak, Direktur Jenderal menempatkan alamat situs tersebut dalam TRUST-Positif dalam periode 24 (dua puluh empat) jam sejak laporan diterima dan dilakukan komunikasi kepada Penyelenggara Jasa Akses Internet.

Pasal 15 Tata cara tindak lanjut laporan dari lembaga penegak hukum atau lembaga peradilan meliputi:

a. Direktur Jenderal menyelesaikan pengelolaan laporan dalam waktu paling lambat 3 (tiga) hari kerja sejak pelaporan diterima;

b. Direktur Jenderal menempatkan alamat situs tersebut ke dalam TRUST-Positif;

c. Direktur Jenderal meminta kepada penyedia atau pemilik situs untuk melakukan pemblokiran atau menghapus muatan negatif apabila situs berupa selain nama domain;

d. Apabila merupakan kondisi darurat, Direktur Jenderal menempatkan alamat situs tersebut dalam TRUST-Positif dalam periode 24 (dua puluh empat) jam sejak laporan diterima dan dilakukan komunikasi kepada Penyelenggara Jasa Akses Internet. 
Tata cara tindak laporan secara umum adalah Direktorat Jenderal melakukan pengelolaan laporan, yang didalamnya terdapat selain pendokumentasian pelaporan, adalah pengambilan sampel situs dan kemudian disimpan. Tahap selanjutnya adalah apabila situs internet dimaksud merupakan situs bermuatan negatif maka dilakukan langkah-langkah pemblokiran seperti yang tertulis diatas.

Dalam Undang-Undang Nomor 19 Tahun 2016 tentang Perubahan Undang-Undang Nomor 11 Tahun 2008 tentang ITE memuat ancaman pidana bagi kejahatan di dunia internet sekaligus juga situs negatif yang ada pada internet. Pada Pasal 45 UU ITE memuat ketentuan pidana bagi perbuatan yang melanggar kesusilaan, perjudian, pencemaran nama baik dan pemerasan atau pengancaman. Berikut bunyi Pasal 45 UU ITE:

Pasal 45

(1) Setiap Orang yang dengan sengaja dan tanpa hak mendistribusikan dan/atau mentransmisikan dan/atau membuat dapat diaksesnya Informasi Elektronik dan/atau Dokumen Elektronik yang memiliki muatan yang melanggar kesusilaan sebagaimana dimaksud dalam Pasal 27 ayat (1) dipidana dengan pidana penjara paling lama 6 (enam) tahun dan/atau denda paling banyak Rp1.000.000.000,00 (satu miliar rupiah).

(2) Setiap Orang yang dengan sengaja dan tanpa hak mendistribusikan dan/atau mentransmisikan dan/atau membuat dapat diaksesnya Informasi Elektronik dan/atau Dokumen Elektronik yang memiliki muatan perjudian sebagaimana dimaksud dalam Pasal 27 ayat (2) dipidana dengan pidana penjara paling lama 6 (enam) tahun dan/atau denda paling banyak Rp1.000.000.000,00 (satu miliar rupiah).

(3) Setiap Orang yang dengan sengaja dan tanpa hak mendistribusikan dan/atau mentransmisikan dan/atau membuat dapat diaksesnya Informasi Elektronik dan/atau Dokumen Elektronik yang memiliki muatan penghinaan dan/atau pencemaran nama baik sebagaimana dimaksud dalam Pasal 27 ayat (3) dipidana dengan pidana penjara paling lama 4 (empat) tahun dan/atau denda paling banyak Rp750.000.000,00 (tujuh ratus lima puluh juta rupiah).

(4) Setiap Orang yang dengan sengaja dan tanpa hak mendistribusikan dan/atau mentransmisikan dan/atau membuat dapat diaksesnya Informasi Elektronik dan/atau Dokumen Elektronik yang memiliki muatan pemerasan dan/atau pengancaman sebagaimana dimaksud dalam Pasal 27 ayat (4) dipidana dengan pidana penjara paling lama 6 (enam) tahun dan/atau denda paling banyak Rp1.000.000.000,00 (satu miliar rupiah).

(5) Ketentuan sebagaimana dimaksud pada ayat (3) merupakan delik aduan.

Pada ayat (1), ayat (2) dan ayat (4) Pasal 45 UU ITE di atas, ancaman hukumannya dipidana dengan pidana maksimal enam tahun penjara. Kecuali pada Pasal 45 ayat (3), di mana informasi elektronik atau dokumen elektronik yang memuat penghinaan atau pencemaran nama baik dipidana paling lama empat tahun. Sebelumnya pada UU Nomor 11 Tahun 2008 tentang ITE, ancaman pidana bagi informasi elektronik atau dokumen elektronik yang memuat penghinaan atau pencemaran nama baik dipidana paling lama enam tahun, sama dengan ayat lainnya dalam pasal tersebut, namun atas tuntutan publik, seperti yang telah dibahas sebelumnya, maka direvisi dan diturunkan ancaman pidananya.

Selain itu, dalam UU ITE yang telah direvisi saat ini, terdapat juga ketentuan pidana bagi orang yang menyebarkan informasi bohong (hoax), orang yang menyebarkan rasa 
kebencian atau permusuhan individu atau kelompok dan juga orang yang melakukan pengancaman melalui informasi elektronik atau dokumen elektronik. ${ }^{10}$ Hal tersebut dijelaskan dalam Pasal 45A dan Pasal 45B UU ITE. Berikut bunyi pasalnya:

Pasal 45A

(1) Setiap Orang yang dengan sengaja dan tanpa hak menyebarkan berita bohong dan menyesatkan yang mengakibatkan kerugian konsumen dalam Transaksi Elektronik sebagaimana dimaksud dalam Pasal 28 ayat (1) dipidana dengan pidana penjara paling lama 6 (enam) tahun dan/atau denda paling banyak Rp1.000.000.000,00 (satu miliar rupiah).

(2) Setiap Orang yang dengan sengaja dan tanpa hak menyebarkan informasi yang ditujukan untuk menimbulkan rasa kebencian atau permusuhan individu dan/atau kelompok masyarakat tertentu berdasarkan atas suku, agama, ras, dan antargolongan (SARA) sebagaimana dimaksud dalam Pasal 28 ayat (2) dipidana dengan pidana penjara paling lama 6 (enam) tahun dan/atau denda paling banyak Rp1.000.000.000,00 (satu miliar rupiah).

Pasal 45B "Setiap Orang yang dengan sengaja dan tanpa hak mengirimkan Informasi Elektronik dan/atau Dokumen Elektronik yang berisi ancaman kekerasan atau menakut-nakuti yang ditujukan secara pribadi sebagaimana dimaksud dalam Pasal 29 dipidana dengan pidana penjara paling lama 4 (empat) tahun dan/atau denda paling banyak Rp750.000.000,00 (tujuh ratus lima puluh juta rupiah)."

Pasal di atas merupakan semangat negara dalam mengawasi peredaran situs negatif yang dapat merugikan masyarakat umum. Meskipun pasal tersebut adalah kejahatan di dunia internet, namun kensekuensi hukumnya tidak kalah besar dari kejahatan konvensional lainnya yang dilakukan di kehidupan nyata.

Penetapan sebuah situs bermuatan negatif atau tidak, tidak dijelaskan secara gamblang dalam Permen Kominfo ini. Pertanyaannya, dapatkah dibuktikan situs yang dianggap bermuatan negatif tersebut adalah kegiatan ilegal yang melanggar hukum, apabila dasar penetapannya adalah melalui laporan dari masyarakat, kementrian dan lembaga serta pemantauan yang dilakukan oleh Direktorat Jenderal Kominfo?

Dilihat dari sudut "perencanaan kebijakan penanggulangan kejahatan dengan hukum pidana" (penal policy), tahap kebijakan legislasi atau formulasi merupakan tahap paling strategis. Kesalahan atau kelemahan kebijakan legislatif merupakan kesalahan strategis yang dapat menjadi penghambat upaya pencegahan dan penanggulangan kejahatan pada tahap aplikasi dan eksekusi.17 sehingga Penegakan Hukum Terhadap Situs Internet Dengan Konten Negatif Melalui Pemblokiran Situs terjadi permasalahan dengan ketidakjelasan pembuktian situs yang dianggap bermuatan negatif tersebut adalah kegiatan ilegal yang melanggar hukum, apabila dasar penetapannya adalah melalui laporan dari masyarakat, kementrian dan lembaga serta pemantauan yang dilakukan oleh Direktorat Jenderal Kominfo.

\footnotetext{
${ }^{10}$ Ketut Krisna Wijaya, Fakta menarik seputar Trust+Positif dari pemerintah dan kontroversi Internet Positif, diakses dari https://id.techinasia.com/pemerintah-trust-positif-internet-positif-iklan fakta, pada tanggal 2 Desember 2018, pukul 04.38 WIB
} 
Oleh karena merupakan esensi dari penegakan hukum, juga merupakan tolok ukur daripada efektivitas penegakan hukum. ${ }^{11}$ Efektivitas perundang-undangan tergantung pada beberapa faktor, antara lain:

a. Pengetahuan tentang substansi (isi) perundang-undangan,

b. Cara-cara untuk memperoleh pengetahuan tersebut.

c. Institusi yang terkait dengan ruang lingkup perundang-undangan di dalam masyarakatnya.

Bagaimana proses lahirnya suatu perundang-undangan, yang tidak boleh dilahirkan secara tergesa-gesa untuk kepentingan instan (sesaat), yang diistilahkan oleh Gunnar Myrdall sebagai undang-undang sapu, yang memiliki kualitas buruk dan tidak sesuai dengan kebutuhan masyarakatnya. ${ }^{12}$

Gangguan terhadap tahap penegakan hukum in abstracto oleh badan pembuat undangundang, tahap disebut juga sebagai tahap kebijakan legislatif, penegakan hukum mungkin terjadi, apabila ada ketidakserasian antara konten yang bermutan negatif atau berunsur SARA layak untuk dilakukan pemblokiran konten tersebut agar tidak menimbulkan terjadinya ketidakserasian antara nilai-nilai yang berpasangan, yang menjelma di dalam kaidah-kaidah yang bersimpang siur, dan pola perilaku tidak terarah yang mengganggu kedamaian nilai- nilai masyarakat.

Peran pemblokiran agar tidak terjadi kejahatan yang dilakukan dengan pemerintah sebagai objek dengan motif melakukan terror, membajak ataupun merusak keamanan suatu pemerintahan yang bertujuan untuk mengkacaukan sistem pemerintahan, atau menghancurkan suatu negara.38 Adapun pemblokiran dimaksud untuk mengurangi timbulnya konten yang bermutan negatif muncul berbagai kasus- kasus terosisem, pornografi, penistaan agama, penyebaran kebencian, perjudian, dan perbuatan illegal, penyebaran informasi yang menimbulkan rasa kebencian atau permusuhan individu dan atau masyarakat komunits maya tertentu berdasarkan atas suku, agama, ras, dan antar golongan (SARA).

Dalam konteks pembuatan regulasi konsep kebijakan untuk tindakan pemblokiran dalam penanggulangan Situs Internet Dengan Konten Negatif di masa mendatang harusnya melihat konsep tentang kebijakan pemblokiran wajib diperhatikan uji tiga rangkai yang diaplikasikan secara kumulatif untuk menentukan apakah kebijakan pemblokiran tersebut memiliki dasar yang kuat yakni; (a) pembatasan tersebut harus berdasarkan hukum yang jelas dan dapat diakses oleh semua orang (prinsip prediktablitias dan keterbukaan); (b) pembatasan itu harus mengacu pada salah satu tujuan yang dijelaskan dalam pasal 19 ayat (3) konvenan yaitu (i) untuk menjaga hak-hak atau reputasi pihak lain, atau (ii) untuk menjaga keamanan nasional atau ketertiban masyarakat atau kesehatan atau moral publik (prinsip legitimasi); dan (c) pembatasan seminimal mungkin (prinisp kepentingan dan keseimbangan).

Berdasarkan uraian diatas, maka seharusnya pemerintah khususnya dengan adanya konten yang bermuatan negatif dan dibentuklah peraturan- pemerintah Undang-Undang Dasar Pasal 28 A - J tahun 1945 tentang HAM dan juga Pasal 19 Kovenan Hak Sipil dan Politik, Undang-Undang Nomor 28 tahun 2014 tentang Hak Cipta, Undang-Undang Nomor 44 tahun 2008 tentang ponografi, Undang-Undang Nomor 19 Tahun 2016 Tentang perubahan UU No.

\footnotetext{
${ }^{11}$ David Holmes Communication Theory Media, Technology ans Society. London: Sage Publishing.2005, hal. 117

${ }^{12}$ Achmad Ali, Menguak Tabir Hukum. Jakarta: Toko Gunung Abadi, 2002, hal. 378-379
} 
11 Tahun 2008 tentang Informasi dan Traksaksi Elektronik (ITE), Undang-Undang Nomor 28 Peraturan Menteri Nomor 19 Tahun 2014 tentang Penanganan Situs Internet Bermuatan Negatif, melalui MenKomInfo, dibuat peraturan tentang kebijakan konten yang bermuatan negatif perlu adanya regulasi agar tidak terjadi salah pemblokiran yang dilakukan oleh ISP karena dengan pemblokiran tampa adanya ketepatan, transparasi dan accountable itu sangat merugikan para penguna konten dan jauh dari dasarkan komunitas maya, seharusnya pemerintah memiliki suatu badan khusus yang independen, kewenangan untuk ISP yang diberikan mandat untuk melakukan pemblokiran konten internet yang bermuatan negatif, seharusnya pemerintah memiliki badan khusus untuk mencegah terjadinya pemblokiran yang tidak transparan dan tidak akuntable.

Sehingga pembuktian suatu perbuatan adalah perbuatan melanggar hukum, harusnya dilakukan melalui pengadilan. Tentu saja tidak cukup dengan dinamika demokrasi Indonesia yang menginginkan keterbukaan dan akuntabilitas dalam setiap tindakan yang dilakukan oleh pemerintah apabila dasar dari penentuan kegiatan ilegal adalah berdasarkan laporan dan pemantauan semata. Mungkin dapat dikecualikan untuk hal-hal yang darurat atau mendesak, dengan menetapkan keadaan yang menyertainya, misalkan tengah dalam proses persidangan atau merupakan konten yang secara jelas ditetapkan terlarang oleh peraturan perundangundangan.

\section{PENUTUP}

\section{Kesimpulan}

Berdasarkan pembahasan yang telah dilakukan, kesimpulan yang dapat Penulis sampaikan adalah:

1. Melalui perubahan UU No. 11 Tahun 2008 tentang Informasi dan Transaksi Elektronik, kewenangan pemerintah dalam menjalankan kewajibannya untuk melindungi kepentingan umum dari segala jenis gangguan sebagai akibat penyalahgunaan informasi elektronik dan transaksi elektronik yang mengganggu ketertiban umum telah diperkuat, yaitu dengan ditambahkannya kewenangan pemerintah untuk melakukan pemutusan akses dan/atau memerintahkan kepada penyelenggara system elektronik untuk melakukan pemutusan akses terhadap informasi elektronik dan/atau dokumen elektronik yang memiliki muatan yang melanggar hukum.

2. Pengertian mengenai konten negatif dan ilegal sebagaimana diatur oleh Permen Kominfo No. 19 Tahun 2014 Tentang Penanganan Situs Internet Bermuatan Negatif dipandang terlalu luas dan multitafsir sehingga rentan merugikan hak warga negara dalam hal informasi serta melanggar prinsip-prinsip demokrasi.

3. Proses penetapan pemblokiran situs internet yang dipandang bermuatan negatif dan ilegal melalui Permen Kominfo No. 19 Tahun 2014 tentang Penanganan Situs Internet Bermuatan Negatif dipandang belum transparan dan akuntabel.

\section{Saran}

Saran yang dapat Penulis sampaikan adalah:

1. Perlu penyempitan ketetapan mengenai pengertian konten negatif dan ilegal dalam situs internet. 
2. Perlu dikembangkan model proses penetapan pemblokiran yang transparan dan akuntabel, seperti misalnya mengembangkan model Forum Penanganan Situs Internet Bermuatan Negatif (FPSIBN) yang pernah ada sebelumnya.

\section{DAFTAR PUSTAKA}

Soerjono Soekanto. Pengantar Penelitian Hukum, cet.3. Jakarta: UI-Press, 1986

Soerjono Soekanto, "Penegakan Hukum dan Kesadaran Hukum”, Naskah Lengkap pada paper pada seminar Hukum Nasional ke IV, Jakarta, 1979

Soerjono Soekanto, Faktor-faktor yang Mempengaruhi Penegakan Hukum, Jakarta: RajaGrafindo Persada, 2004

David Holmes Communication Theory Media, Technology ans Society. London: Sage Publishing. 2005

Achmad Ali, Menguak Tabir Hukum. Jakarta: Toko Gunung Abadi, 2002.

Undang-undang Nomor 11 Tahun 2008 Tentang Informasi dan Transaksi Elektronik

Undang-undang Nomor 19 Tahun 2016 Tentang Perubahan Atas Undang-undang Nomor 11 Tahun 2008 Tentang Informasi dan Elektronik

Peraturan Menteri Komunikasi dan Informatika Nomor 19 Tahun 2014 Tentang Penanganan Situs Internet Bermuatan Negatif

Ketut Krisna Wijaya, Fakta menarik seputar Trust+Positif dari pemerintah dan kontroversi Internet Positif, diakses dari https://id.techinasia.com/pemerintah-trust-positif-internetpositif-iklan fakta, pada tanggal 2 Desember 2018, pukul 04.38 WIB

https://tirto.id/aksi-blokir-situs-oleh-pemerintah-bermanfaatkahcGf7?gclid=Cj0KCQjw6J7YBRC4ARIsAJMXXsdFto18juU_jWx8Yf_XyLuijnN7Pp U9DnFLPorE6pGQQeK wkbJxwgaAnXSEALw wcB

https://tirto.id/ketika-pemerintah-makin-digdaya-memblokir-situsnbsp-nbsp-b5tq

https://irto.id/mencari-mekanisme-pemblokiran-yang-tepat-b5tK 